\title{
Use of Instructional Media in Elementary Schools in Kenya: Understanding Teacher Attitude and Perceived Pedagogical Value of Picture Books
}

\author{
Florence Chacha ${ }^{1}$, Samwel Mwanda ${ }^{1}$, Ronnie Midigo ${ }^{2, *}$ \\ ${ }^{1}$ Department of Educational Communication and Technology, University of Nairobi, Nairobi, Kenya \\ ${ }^{2}$ Institute of Anthropology, Gender and African Studies, University of Nairobi, Nairobi, Kenya
}

Email address:

florencegatichacha@gmail.com (F. Chacha), samwelmwanda@gmail.com (S. Mwanda), ronniemidigo@gmil.com (R. Midigo)

${ }^{*}$ Corresponding author

To cite this article:

Florence Chacha, Samwel Mwanda, Ronnie Midigo. Use of Instructional Media in Elementary Schools in Kenya: Understanding Teacher Attitude and Perceived Pedagogical Value of Picture Books. International Journal of Elementary Education.

Vol. 6, No. 6, 2017, pp. 47-54. doi: 10.11648/j.ijeedu.20170606.11

Received: December 4, 2017; Accepted: December 14, 2017; Published: January 18, 2018

\begin{abstract}
Picture books are instructional materials normally designed as learning aids. They combine visual and verbal narratives in a book format. The images in picture books use a range of media such as oil paints, acrylics, watercolour, and pencil, among others [1]. Teachers resort to use of picture books for instruction as a method through which the standard classroom environment could be minimized. The purpose of this study was to assess teachers of English's attitudes and beliefs about the pedagogical value of using picture books for teaching English oral skills to pre-school pupils. The study was guided by the Two Factor Theory developed by Herzberg (1968) which suggests that people are influenced by two factors which motivate their performance namely motivators and hygiene factors. Thus the interplay of factors which influenced pre-primary school teachers of English to use picture books as instructional materials in this study included, attitude, perceptions of effectiveness, availability and perceived pedagogical value of the materials. The study used descriptive survey design to get information from all the elementary school teachers in the study area. The data was analysed using descriptive statistics which involved tabulation of data into frequencies, percentages, mean and standard deviations. Analysis of the results revealed that teachers were aware and appreciated the pedagogical value of picture books for training but however had mixed attitude towards its use. The study revealed a need to develop policy frameworks by Ministry of Education (MoE) and the Kenya Institute of Curriculum Development (KICD) to ensure accurate planning for better remuneration, integration of instructional materials in the curriculum and availability of infrastructure conducive for better elementary education and other similar studies in different areas utilizing qualitative or mixed methods to delve into other underlying issues for poor utilization of picture books as instructional materials.
\end{abstract}

Keywords: Pedagogy, Attitude, Picture Books, Learning Outcome

\section{Introduction}

Language teaching has been described as the foundation of all instructional process [1]. As such educationists have been seeking ways through which teaching of foreign languages could be enhanced. This has led to the changing of focus of language teaching to promotion of oral skills in order to respond to learner's needs for effective communication [2, 3]. One way through which learning of oral skills could be enhanced is through the use of instructional materials such as picture books. Use of picture books for training elementary education pupils makes learning interesting, interactive and relational. This is because it helps the teacher clarify abstract concepts to the young children who are in their formative years. These picture books are available and can be used in areas with no electricity supply, are easy to assemble and use. Besides, educationists advises that since development of language skills in early years is influenced much by the child's immediate environment, learning should be organized in such a way that it offers rich and valid experience that 
support and stimulate their development. All this could be made possible through the use of instructional materials such as picture books [4]. However, studies show that pre-primary school teachers exhibit low utilization of instructional media during teaching.

Pictures aid learners not only in oral skills, but also in many other aspects of foreign language teaching. Reference [5] demonstrated how pictures could be used to achieve various milestones in instructional process. He used a compiled picture and illustrated the picture could be used in achieving instructional objectives in five very different language areas. The areas in his example included structure, vocabulary, functions, situations and oral skills. The scholar further pointed out that the prospective of pictures is so wide that only its elements could be described in his book. Pictures also serve to provide a sense of the context of the language as well as specificity of reference point or stimulus [6]. This aspect aids a learner in memory and mental concept image association. At the elementary levels, learners rely more on their ability to memorize and associate object with skills learnt [7]. It is for this purpose that use of instructional pictures becomes necessary for training elementary education pupils.

Pictures have also been described as suitable for any group of learners, independently on age or level and that they can also be used in various levels of learning. As such, pictures can be used for all the levels of learning including the cognitive domains of learning, Knowledge, Comprehension, application, analysis, synthesis and evaluation as described by Bloom [8]. Other scholars also listed advantages of use of pictures in the instructional process to include their being available since they could be obtained in any magazines, on the internet, etc.; they are cheap, often free; they are personal (teacher selects them); flexible since they could easily be kept, could be used for various types of activities such as drilling and comparing, and that they are always fresh and different since they come in various formats and styles. Use of pictures always leaves the learners wondering what comes next [9].

In a classroom environment with pictures as instructional materials, learners always pay attention and are curious about what is expected of them of the pictures shown. This serves to draw the attention of the learners and creating and raising inquisitively. According to the constructivist approaches in learning, this aspect of curiosity is vital in knowledge construction by the learners [9].

Pictures however, have their limitations too. According to a study conducted by reference [10], pictures could not be used to sufficiently demonstrate for instance meaning all words. Such may include abstract words such as opinion or impact. In such instances, other tools could be used to demonstrate meaning or alternatively be supplemented by other tools. Use of pictures could also be time consuming. Instructors spend a lot of time to find the right pictures for a specific type of activity. As such, teachers must have own collection of instructional pictures. This challenge can however be overcome by the fact that such collections can be used over a long period of time with different learners [9].

While using pictures, instructors ought to be able to apply effective strategies to ensure that learners utilize the input through as many channels as possible. As such, instructors should include variety of stimuli in teaching. Instructors therefore advise that, while using pictures as instructional materials, it is important to find a balance and not to use pictures entirely. For effective learning, they should be combined with other techniques and different types of stimuli such as movement, verbal stimuli and sound. Additionally, pictures used for demonstration of the meaning should be repeatedly connected with the spoken and subsequently also written form of the word or chunk of language [1].

Elementary education or Early Childhood Development Education (ECDE) in Kenya has been recognized as a crucial program that lays a foundation for a child's holistic and integrated education. Elementary education serves to meet the cognitive, social, moral, spiritual, emotional, physical and developmental needs of a child. It is the first formal agent of socialization and as such defines the nature of our society [11].

Teaching and learning materials are critical ingredients in learning. No meaningful teaching and learning takes place without adequate materials [12]. Learning materials therefore must be made available for learners in adequate quality and quantities, and at the required time. These materials serve to inform schemes of work and lesson notes preparation. This study investigated the effectiveness of picture books as training materials in teaching Oral Skills to elementary education pupils in Tigoni Division, Kenya

\section{Literature Review}

\subsection{Picture Books as Instructional Aid}

Studies on the use of picture books as instructional materials began to be taken seriously during the latter years of the twentieth century. The first major works in application of picture books as instructional aids in English were done by two scholars; Joseph Schwartz and Perry Nodelmann in their books; Ways of the Illustrator and Words About Pictures in the 1980s [13]. It was from these pioneer researchers that other scholars started coming up with articles, conference papers and book chapters dedicated to the study, criticism and analysis of the picture book. The contribution of picture books in instruction is based on the combination of two levels of communication, the visual and the verbal [14].

According to reference [15], picture books creates a miniature ecosystem in for enhanced learning experience. This is brought about by the reciprocating actions of words and pictures in picture books where each one becoming the environment within which the other lives and thrives. Other scholars have described this interaction as creation of impressions of exciting, stimulating and a vibrant branch of children's literature $[14,16]$.

Picture books speak to us of childlike qualities, of youthful simplicity and youthful cheerfulness; yet puzzlingly, they do 
so in terms that implies a vast sophistication in regard to both visual and verbal codes. Indeed, it is part of the literary charm of many of the most interesting picture books that they so strangely combine the childlike and the sophisticated that the viewer they imply is both very learned and unsophisticated [17].

Since most children start looking at picture books at the age of two or three and continue to take pleasure in them for several years to come, use of picture books therefore is a fundamental instructional model that can work for many children across cultures in time and space [18]. Parents, as the first agents of socialization introduce picture books to their children at home where they read texts aloud and point out interesting features to their children. This interaction is normally found to be interesting for children as they take part in the story. As such, picture books are designed for children because they use pictures to tell a story. In some cases, the picture book may be used to convey a story entirely through pictures, without any text at all while in other cases; they may be accompanied by text. In both cases, the picture book is intelligently designed to introduce young children to the idea of books as well as reading [19].

\subsection{Pedagogical Value of Using Picture Books for Instructional Purposes}

Educators are always searching for effective ways to increase the literacy levels of their students. Best pedagogical approaches ought to be learner and learning centred. As such the approach should promote academic achievement, social and emotional development, acquisition of technical skills, and a general ability to contribute to society.

Due to their various features and pedagogical value, picture books have started to find their place in many ECE classrooms [19]. They have been used in language learning classrooms to teach different language skills including reading writing, speaking and listening [20]. Besides, picture books were used to enhance learners' critical thinking and basic literacy skills [21].

For example, Hsiu-Chih [22] investigated the effectiveness of children's picture books in Taiwanese classrooms where English is taught as a foreign language. The study emphasized on the teachers' perceptions of using children's picture books in the English language classrooms. Teachers' perceptions in the study revealed some fundamental educational values of using children's picture books in English language learning classrooms. Findings indicated that children's picture books had linguistic benefits in which learners could improve their vocabulary learning, reading, and critical thinking. Along the same line, illustrations of picture books could help to trigger students' motivation in learning. Finally, using picture books was helpful to assist pupils to actively engage in the classroom when they learn from them.

In another study conducted by Ho [23], English language learners were taught literacy and language courses using picture books for three years. The learners who participated in the study were divided into three groups of 20 students each. The students were observed and interviewed at the end of the course period. The results showed that generally, students participated positively in most language, literacy tasks, and activities that included pronunciation, developing literacy competence, critical reading, and multicultural awareness. The result of this study is a demonstration that picture books pedagogically sound for instructional purposes for different learning needs.

Moreover, considerable numbers of studies were conducted to investigate the role of children's picture books in developing different language and literacy abilities of English language learners [21, 24].

\subsection{Attitude Towards Use of Picture Books for Instruction}

Teachers need to be equipped with a diverse repertoire of effective methods and strategies in teaching. Such knowledge will aid the teacher make day-to-day instructional decisions [25]. Use of picture books as instructional materials are very important as they help educators develop productive educational experiences for student's needs [18]. Curriculum development institutions should be able to suggest learning materials based their experience for instructional purposes for disciplines such as English language [18]. Most instructors are aware that better learning outcomes are achieved when instructional materials such as picture books are included in in the learning process. The resources should be used as an integral part of learning activity to achieve the highest level of understanding within the context of their subject matter [14].

Attitude refers to the settled ways of thinking that individuals use to decide their approval [15]. Teachers need to have positive attitude for them to effectively use picture books as instructional materials for teaching elementary education pupils [17]. To achieve this, they need to acquire two fundamental types of knowledge that will enable them to design and carry out meaningful learning experiences for their students: pedagogical and content knowledge [26]. For educators to effectively teach oral skills in English, they must acquire a deep understanding of the subject, and how to teach it, to improve learners learning achievement and understanding of the subject [27].

In a study conducted by reference [28], teachers generally had positive attitude towards use of instructional materials in general. This she attributed to the fact that teachers believed that use of instructional materials had the potential of improve learner participation. Another study conducted by reference [29] also affirmed positive attitude demonstrated by teachers on use of instructional materials but concludes that challenges of implementing use of instructional materials in classrooms may discourage their use and this could possible impact on their attitude on the same.

Nonetheless, a study conducted by reference [30] concluded that teachers with a positive attitude toward instructional materials were more likely to use them in the instructional process. The study however, links positive attitude to knowledge and suggests that teacher professional development programs must bring out enthusiasm for learning the subject and improve teacher's subject knowledge 
which would motivate them to use instructional materials for improved learning outcome [30].

\subsection{Problem Statement}

Language teaching has been described as the foundation of all instructional process [2]. As such educationists have been seeking was through which teaching of foreign languages could be enhanced. This has led to the changing of focus of language teaching to promotion of promotion of oral skills in order to respond to learner's needs for effective communication [3]. One way through which learning of oral skills could be enhanced is through the use of instructional materials such as picture books. Use of picture books for training elementary school pupils makes learning interesting, interactive and relational. This is because it helps the teacher clarify abstract concepts to the young children who are in their formative years. These picture books are available and can be used in areas with no electricity supply, are easy to assemble and use. Besides, educationists advises that since development of language skills in early years is influenced much by the child's immediate environment, learning should be organized in such a way that it offers rich and valid experience that support and stimulate their development. All this could be made possible through the use of instructional materials such as picture books [4]. However, studies show that pre-primary school teachers exhibit low utilization of instructional media during teaching.

A study conducted by reference [28] investigated the effects of use of instructional material on participation of preschool pupils in science classroom in Kirinyaga County and concluded that there was lack of effective use of instructional materials among elementary school teachers due to large number of enrolment and lack of infrastructure to accommodate activities. Another study conducted by reference [29] in Tanzania conducted in primary school units found out that instructional materials were inadequate in most schools and that the teacher-pupil ratio in these schools was too large to accommodate us of instructional materials including picture books. Also noted were poor classroom arrangement and small space. The researcher further noted that although the children enjoyed learning by using instructional materials, they were hardly utilized and recommended increased investment on pre-primary education especially those pre-primary units established in public primary schools.

While use of instructional materials including picture books in the above studies were found to be effective in increasing learner participation, it is possible that other factors including teacher beliefs, attitudes and skills could influence use of such materials. Besides, the studies described above have specificity as regards methodology, setting and subject. This study will therefore fill the knowledge gaps exhibited above by investigating the perceived pedagogical value as well as teachers' attitude towards use of picture books in teaching pre-school pupils English oral skills in Tigoni Zone of Limuru Sub County Kiambu County.

\subsection{Purpose and Objectives}

The purpose of this study is to explore the perception of elementary education teachers on the pedagogical value of use of picture books for teaching English oral skill. The study also aims at examining the attitude of teachers towards use of picture books in teaching English oral skills to elementary school pupils. With this understanding, it is expected that educational stakeholders like the Ministry of Education, teachers, school inspectors, parents and the Kenya Institute of Curriculum Development (KICD) and other practitioners will be equipped with knowledge on use of instructional materials in elementary schools. Further, the study contributes to the effective utilization of instructional materials especially the use of picture books which are often available and easy to assemble. Also it will be useful for policy makers and curriculum developers in provision of quality universal education in elementary school

\subsection{Theoretical Context}

This study was guided by the Two Factor Theory developed by Herzberg [31]. The theory suggests that people are influenced by two factors which motivate their performance namely motivators and hygiene factors. The theory is based on factors that motivate workers to perform in order to achieve set objectives. In this study the interplay of factors which influenced pre-primary school teachers of English to use picture books as instructional materials included, attitude, perceptions of effectiveness, availability and perceived pedagogical value of the materials.

The theory provides that motivation may be extrinsic or intrinsic. In this study the teacher's attitude, perceptions and approval towards use of picture books were intrinsic factors. Motivators like promotion, recognition for and support in the use of picture books as instructional materials may encourage use but were not investigated in this study. In the teaching context, the hygiene factors that would influence tutors to use instructional media would include working conditions and the quality of the facilities for storage of instructional materials.

This theory is relevant to this study because motivation which is a very important variable in this study plays an essential role in every human behaviour and influences human conduct. How pre-primary school teachers would use instructional materials in teaching may also depend on the motivation they receive from the managers of the schools which may be in form of time, support, encouragement, appreciation, rewards, provision of instructional materials, and provision of technical support.

\subsection{Conceptual Framework}

Reviewed literature points to effectiveness of picture books for instructional purposes. The conceptualized variables of this study for effective utilization of picture books for instruction included the pedagogical value of picture books as instructional materials, attitude toward use, perceived effectiveness and the actual utilization of the 
materials. Figure 1 shows the variables which influence effective use of picture books as instructional materials in teaching oral skills in English to pupils. When these factors are inadequate, the situation leads to underutilization of

Independent Variable

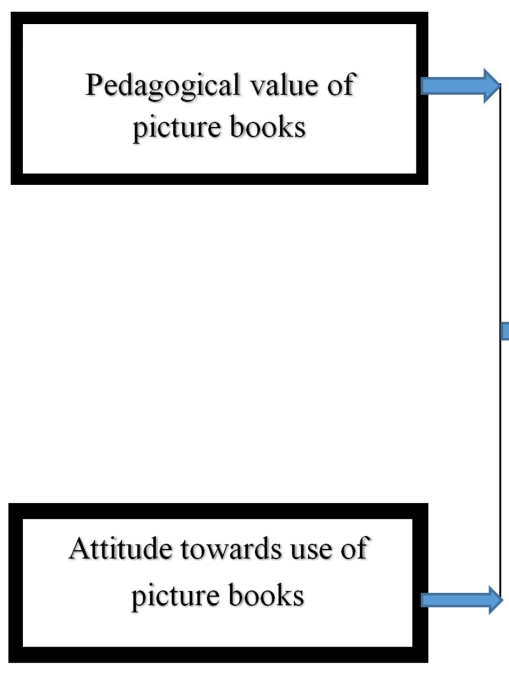

picture books as instructional materials. The utilization of picture books for teaching in in turn improves learning outcomes. Figure 1 illustrates the conceptual framework.

Figure 1. Conceptual framework.

\section{Methodology}

The study adopted cross sectional survey design. Participants in the study were elementary school teachers in Tigoni Zone of Kiambu County, Kenya. They were asked questions related to use of picture books as instructional media. The questions were in Likert form and tested their perceptions and attitude. The study used descriptive statistics (percentages, mean and standard deviations for data interpretation).

\section{Results}

Likert scale questions were asked and teachers instructed to indicate their levels of agreement where $\mathrm{SA}=$ Strongly Agree, $\mathrm{A}=$ Agree, $\mathrm{N}=$ Neutral, $\mathrm{D}=$ Disagree and $\mathrm{SD}=$ Strongly Disagree. The mean and standard deviation values were used to interpret majority responses. The results are presented in tables.

\subsection{Demographic Information}

Respondents were asked to indicate their ages, levels of education, gender and experience teaching elementary education pupils. Table 1 represents the findings.

Table 1. Demographic information of the respondents.

\begin{tabular}{llll}
\hline & Category & Returned & \% \\
\hline \multirow{3}{*}{ Age } & Below 25 yrs & 16 & 31.4 \\
& $25-35$ yrs & 26 & 51.0 \\
Level of education & 36-55 yrs & 7 & 13.7 \\
& Above 55 yrs & 2 & 3.9 \\
\hline
\end{tabular}

\begin{tabular}{llll}
\hline & Category & Returned & \% \\
\hline \multirow{4}{*}{ Gender } & Certificate holders & 27 & 52.9 \\
& Untrained & 7 & 13.7 \\
\multirow{3}{*}{ Experience } & Male & 11 & 21.6 \\
& Female & 40 & 78.4 \\
& $0-5$ yrs & 13 & 25.5 \\
& 6-10 yrs & 31 & 60.8 \\
\hline
\end{tabular}

From the table, $51.0 \%$ the respondents were aged between 23-35 years. About 3.9\% were aged above 55 years. Those who were below 25 years were $31.4 \%$. The results shows that majority of the teachers were aged between 25-35 years.

Of the sampled respondents, those who had diploma education were $33.3 \%$, while those with certificates were $52.9 \%$. About $13.7 \%$ were untrained teachers. The finding shows that most teachers are certificate holders and a few untrained teachers. Male teachers formed $21.6 \%$ of the sampled population while female teachers were $78.4 \%$. This finding indicates that majority of the teachers are female. Male teachers only comprised a small percentage of $21.6 \%$. The study also found that $60.8 \%$ of the teachers who participated in the study had $6-10$ years of experience, $24.4 \%$ had between $0-5$ years of experience while $13.7 \%$ had more than 10 years. This reveals that most teachers who participated in the study had between 6-10 years of experience.

\subsection{Perceived Pedagogical Value of Use of Picture Books}

To assess the teacher's beliefs about the pedagogical value of using picture books as instructional materials for teaching elementary school pupils oral skills, likert type questions were asked and the respondents asked to indicate their levels of agreement with the statements. Table 2 represents the 
descriptive statistics of the findings

Table 2. Teacher's beliefs about the pedagogical value of picture books.

\begin{tabular}{|c|c|c|c|c|c|c|c|}
\hline & SD & D & $\mathbf{N}$ & $\mathbf{A}$ & $\mathbf{S A}$ & Mean & SD \\
\hline Picture books are both fun and full of pedagogical value. & $7.8 \%$ & $21.6 \%$ & $9.8 \%$ & $23.5 \%$ & $37.3 \%$ & 3.61 & 1.39 \\
\hline Picture books should be given special role in teaching oral skills. & $13.7 \%$ & $17.6 \%$ & $5.9 \%$ & $17.6 \%$ & $45.1 \%$ & 3.6 & 1.51 \\
\hline $\begin{array}{l}\text { picture books present many opportunities to learners to show their skills not only } \\
\text { in oral skills but also in many language areas }\end{array}$ & $13.7 \%$ & $15.7 \%$ & $7.8 \%$ & $21.6 \%$ & $41.2 \%$ & 3.64 & 1.55 \\
\hline Teachers must use picture books for fun only for breaking down boredom. & $33.3 \%$ & $21.6 \%$ & $27.5 \%$ & $11.8 \%$ & $5.9 \%$ & 2.35 & 1.23 \\
\hline picture books stimulate learner creativity & $0.0 \%$ & $5.9 \%$ & $25.5 \%$ & $41.2 \%$ & $27.5 \%$ & 3.9 & 0.88 \\
\hline picture books encourages collaborative learning & $0.0 \%$ & $9.8 \%$ & $19.6 \%$ & $33.3 \%$ & $37.3 \%$ & 3.98 & 0.99 \\
\hline
\end{tabular}

The results show that $37.3 \%$ of the teachers strongly agreed that picture books are both fun and full of pedagogical value. About $23.5 \%$ also agreed with the statement. This finding indicates that most of the respondents agreed with the statement $(\mathrm{M}=3.61, \mathrm{SD}=1.39)$. Similarly, $45.1 \%$ and $17.6 \%$ strongly agreed and agreed respectively that picture books should be given special role in teaching oral skills. Those who strongly disagreed and disagreed with the statement were $13.7 \%$ and $17.6 \%$ respectively. The mean and standard deviation values for the question $(\mathrm{M}=3.60, \mathrm{SD}=1.51)$ thus indicates that most of the respondents were in agreement with the statement.

As to whether picture books present many opportunities to learners to show their skills not only in oral skills but also in many language areas, $41.2 \%$ of the respondents indicated that they strongly agreed with the statement. Those who agreed represented $21.6 \%$ of the respondents while those who disagreed and strongly disagreed were $15.7 \%$ and $13.7 \%$ respectively. This response generated a mean value of 3.64 and a standard deviation value of 1.55 indicating that majority of the respondents agreed with the statement. Also investigated was whether teachers could only use picture books for breaking boredom. About 33.3\% of the sampled teachers strongly disagreed with the statement with another $21.6 \%$ disagreeing. It also worth noting that about $27.5 \%$ of the teachers neither agreed nor disagreed. Those who agreed with the statement were $5.9 \%$. The mean and standard deviation values $(\mathrm{M}=2.35, \mathrm{SD}=1.23)$ indicate that most of the respondents disagreed with the statement.

The study also revealed that $41.2 \%$ and $27.5 \%$ of the teachers Agreed and strongly agreed respectively that picture books stimulate learner creativity. While $25.5 \%$ of them were neutral, $5.9 \%$ disagreed. On average, a majority $(\mathrm{M}=3.9$,
$\mathrm{SD}=0.88$ ) agreed that indeed picture books stimulate learner creativity. Likewise, $37.3 \%$ and $33.3 \%$ of the respondents strongly agreed and agreed respectively that picture books encourage collaborative learning. The Mean and standard deviation values $(\mathrm{M}=3.98, \mathrm{SD}=0.99)$ also indicated that a majority of the teachers agreed with the statement.

The above findings indicate that most teachers understand and appreciate the pedagogical value of picture books. This finding agrees with studies conducted by reference [32] which revealed that teachers believe that use of picture books added fundamental educational values in English language learning classrooms. Reference [32] categorized these pedagogical values into the linguistic value, the value of the stories, and the value of the pictures which both added unique pedagogical qualities in the learning process.

Moreover, the belief that picture books enhance learner creativity and collaborative learning was also advanced in the studies conducted by references [18, 33 and 34]. The scholars revealed that educators need to encourage today's emerging readers to use picture books as a way to see new forms, images and intersections that are vital spaces for collaborative imagination and inquiry. Similarly, the scholars provide that picture books have the potential to not only secure a set of technical skills, but also to imagine, to think outside the box of conventions and to move into the powerful area where true meaning and aesthetic creation reside.

\subsection{Attitude Towards Use of Picture Books}

Attitude of teachers towards use of picture books for teaching oral skills was also investigated through a set of likert scale type questions. Table 3 shows the attitude of the sampled teachers

Table 3. Attitude towards use of picture books for instruction.

\begin{tabular}{|c|c|c|c|c|c|c|c|}
\hline & SD & D & $\mathbf{N}$ & A & SA & Mean & SD \\
\hline $\begin{array}{l}\text { I believe that I cannot measure pupil's oral skills when I use picture books in my } \\
\text { classroom }\end{array}$ & $31.4 \%$ & $23.5 \%$ & $15.7 \%$ & $11.8 \%$ & $17.6 \%$ & 2.65 & 1.49 \\
\hline $\begin{array}{l}\text { I believe that using picture books to teach oral skills may distract learner's } \\
\text { attention during the instruction. }\end{array}$ & $27.5 \%$ & $33.3 \%$ & $19.6 \%$ & $13.7 \%$ & $5.9 \%$ & 2.37 & 1.20 \\
\hline I believe that using picture books in my oral skills class can be time-consuming & $13.7 \%$ & $19.6 \%$ & $17.6 \%$ & $27.5 \%$ & $21.6 \%$ & 3.24 & 1.37 \\
\hline I feel uncomfortable when I don't give the exact rules use of picture books. & $11.8 \%$ & $13.7 \%$ & $17.5 \%$ & $35.3 \%$ & $11.8 \%$ & 3.22 & 1.19 \\
\hline I find it difficult to find a picture for every aspect of oral skills lessons & $9.8 \%$ & $17.6 \%$ & $13.7 \%$ & $43.1 \%$ & $15.7 \%$ & 3.35 & 1.21 \\
\hline
\end{tabular}

About $31.4 \%$ of the respondents strongly disagreed that they could not measure pupil's oral skills when they use picture books in classroom. Another $23.5 \%$ disagreed while $17.6 \%$ and $11.8 \%$ strongly agreed and agreed respectively. A mean value of 2.65 and standard deviation of 1.49 indicated that most of the respondents neither agreed nor disagreed with the 
statements. Similarly, most of the respondents $(27.5 \%$ and $33.3 \%$ ) strongly disagreed and disagreed that using picture books to teach oral skills may distract learner's attention during the instruction. Those who neither agreed nor disagreed were $19.6 \%$. Mean score and standard deviation values $(\mathrm{M}=2.37, \mathrm{SD}=1.20)$ indicated that most of the respondents were neutral on whether picture books would distract learners.

As to whether use of picture books could be time consuming, $27.5 \%$ and $21.6 \%$ agreed and strongly agreed respectively. Those who disagreed with the statement were $19.6 \%$ while those who strongly disagreed were $13.7 \%$. The mean and standard deviation values obtained $(\mathrm{M}=3.24$, $\mathrm{SD}=1.37$ ) indicate that most of the respondents neither agreed nor disagreed with the statement. Similarly, 35.3\% of the respondents agreed that they were uncomfortable when they don't give the exact rules on use of picture books. About $17.5 \%$ were neutral. Mean value of 3.22 and standard deviation of 1.19 revealed that most respondents neither agreed nor disagreed with the statement.

About $43.1 \%$ of the respondents agreed that they found it difficult to find a picture for every aspect of oral skills lessons and another $15.7 \%$ strongly disagreed. On the other hand $17.6 \%$ disagreed with the statement while $9.8 \%$ strongly disagreed. The responses produced a mean value of 3.35 and 1.21 indicating that the respondents were mostly neutral.

Overall, the findings of this study indicate that teachers have mixed attitude towards use of picture books as instructional materials for teaching oral skill to elementary school pupils. Nonetheless, studies indicate that most teachers are aware of the better learning outcomes associated with use of instructional materials such as picture books $[14,15]$. With this kind of awareness, it is expected that teachers would have positive attitude towards their use [17]. In the previous section of this work, the study revealed that teachers were aware and appreciated the pedagogical value of picture books as instructional materials. It is therefore possible that extrinsic factors contributed to the finding in this section. Studies conduct conducted by references [28, 29] in Kenya and Tanzania respectively revealed that even though teachers were willing to use of instructional materials such as picture books in their instructional processes, they faced several challenges including large number of enrolment, lack of infrastructure to accommodate activities, inadequate instructional materials, few teachers in schools with large population, poor classroom arrangement and inadequate time allocated for the lessons. Such factors could have influenced the teacher's attitude towards use of picture books as instructional materials.

A study conducted in Kenya by reference [35] however, indicated that teachers had negative attitude towards the use of instructional materials in general. And this he attributed to the shortcomings of the materials themselves as well as the other demotivating factors both intrinsic and extrinsic. This he also attributed to the fact that Early Childhood Education (ECE) teachers are not employed by the central government and that it could be possible that the salaries paid to them could not be commensurate with their workload.

\section{Conclusions}

The Following the results of the study, it can therefore be concludes that teachers understand and appreciate the pedagogical value of picture books for teaching orals skills. However, teachers have mixed attitude towards use of picture books as instructional materials for teaching pupils oral skills. This was occasioned by their appreciation of pedagogical value of picture books for training against the fact that they were demotivated by large pupil to teacher ratio, poor infrastructure and poor remuneration.

\section{Recommendations}

Based on the findings of this study, it is recommended that a policy framework be developed by the Ministry of education (MoE) and the Kenya Institute of Curriculum Development (KICD) to ensure accurate planning for better remuneration, integration of instructional materials in the curriculum and availability of infrastructure conducive for better elementary education.

Methodologically, the study recommends similar studies in different areas covering both rural and urban set ups, larger populations. Such studies could also utilize qualitative or both qualitative and quantitative methods to delve into underlying issues in effective use of picture books for teaching elementary education pupils which were beyond the scope of the current study.

For practice, more information could be passed to the teachers to ensure compliance to sound pedagogical approaches. This would improve their attitude towards the use instructional materials in general which would lead to better learning outcomes in the area. Elementary school management should also be sensitized on the importance of using instructional materials such as picture books to ensure their support for the teachers.

\section{References}

[1] Pilgrim, J., \& Ward, A. K. (2017). Universal Design for Learning: A Framework for Supporting Effective Literacy Instruction. In Handbook of Research on Classroom Diversity and Inclusive Education Practice (pp. 282-310). IGI Global.

[2] Aktaş, C, B (2017). Listening to Young Children: Applying Montessori's Method to English as an Additional Language (EAL) Education, International Journal of Elementary Education. Vol. 6, No. 1, 2017, pp. 1-7. doi: 10.11648/j.ijeedu.20170601.11.

[3] Hinkel, E. (2017). Teaching Speaking in Integrated-Skills Classes. The TESOL Encyclopaedia of English Language Teaching.

[4] Stone, J. (2016). Assessing the Impact of Picture Books in Primary Grades Mathematics Instruction.

[5] Scott, W. A., \& Ytreberg, L. H. (1990). Teaching English to children. eLondon London: Longman.

[6] McDonough, J., \& McDonough, S. (2014). Research 
[7] Brophy, J., Alleman, J., \& Halvorsen, A. L. (2016). Powerful social studies for elementary students. Cengage Learning.

[8] Bloom, B. S. (1989). Engelhart, MD, Furst, EJ, Hill, WH, \& Krathwohl, DR (1956). Taxonomy of educational objectives: The classification of educational goals. Handbook 1: Cognitive domain.

[9] Arends, R. (2014). Learning to teach. McGraw-Hill Higher Education.

[10] Reyna, V. F., Corbin, J. C., Weldon, R. B., \& Brainerd, C. J. (2016). How fuzzy-trace theory predicts true and false memories for words, sentences, and narratives. Journal of applied research in memory and cognition, 5 (1), 1-9.

[11] Ng'asike, J. T. (2014). African early childhood development curriculum and pedagogy for Turkana nomadic pastoralist communities of Kenya. New directions for child and adolescent development, 2014 (146), 43-60.

[12] Kolb, D. A. (2014). Experiential learning: Experience as the source of learning and development. FT press.

[13] Newell, K. (2017). Expanding Adaptation Networks: From Illustration to Novelization. Springer.

[14] Unsworth, L. (2017). Image-Language Interaction in Text Comprehension: Reading Reality and National Reading Tests. In Improving Reading and Reading Engagement in the 21st Century (pp. 99-118). Springer Singapore.

[15] Fattal, L. F. (2017). Visual Culture in the Elementary-School Classroom: Moving from Box-Store Commodities to Out-ofthe-Box Thinking. The New Educator, 13 (4), 350-368.

[16] Gilmore, L., \& Howard, G. (2016). Children's books that promote understanding of difference, diversity and disability. Journal of Psychologists and Counsellors in Schools, 26 (2), 218-251.

[17] Cox, P. (2017). The Child Mechanical and Adult Anxiety in Children's Literature and Culture:" Wheels to the Rails!" Jeunesse: Young People, Texts, Cultures, 8 (2), 19-35.

[18] Pinter, A. (2017). Teaching young language learners. Oxford University Press.

[19] Livingston, T., Oswald, H., \& Skinner, J. (2016). Play By Design: The World of Children's Books.

[20] Zhou, W., \& Li, G. (2017). The Effects of Shared Singing Picture Book Instruction on Chinese Immersion Kindergarteners' Spoken Vocabulary Recall and Retention. Frontiers of Education in China, 12 (1), 29-51
[21] Gooch, R., Saito, K., \& Lyster, R. (2016). Effects of recasts and prompts on L2 pronunciation development: Teaching English/I/to Korean adult EFL learners. System, 60, 117-127.

[22] Hsiu-Chih, S. (2008). The value of English picture story books. ELT journal, 62 (1), 47-55.

[23] Ho, W. K., \& Wong, R. (2000). Language policies and language education: The impact in East Asian countries in the next decade. Marshall Cavendish Intl.

[24] Strasser, J., \& Seplocha, H. (2007). Using picture books to support young children's literacy. Childhood Education, 83 (4), 219-224.

[25] Mahmoud Kamal Ibrahim Mostafa, The Effect of Chants and Short Stories on Primary Stage Pupils' Communication and Attitudes, International Journal of Elementary Education. Vol. 6, No. 4, 2017, pp. 38-41. doi: 10.11648/j.ijeedu.20170604.12.

[26] Barner, D., Brooks, N., \& Bale, A. (2011). Accessing the unsaid: The role of scalar alternatives in children's pragmatic inference. Cognition, 118 (1), 84-93.

[27] Teo, T., Milutinović, V., \& Zhou, M. (2016). Modelling Serbian pre-service teachers' attitudes towards computer use: A SEM and MIMIC approach. Computers \& Education, 94, 77-88.

[28] Wambui, S. E. (2013). Effect of Use of Instructional Materials on Learners' Participation in Science Classroom in Preschool in Kiine Zone Kirinyaga County Kenya. Unpublished M. Ed Project.

[29] Mwalyego, M. S. (2014). An investigation on the utilization of instructional materials in pre-primary schools in Morogoro municipal council (Doctoral dissertation, The Open University of Tanzania).

[30] Pressley, M., \& Allington, R. L. (2014). Reading instruction that works: The case for balanced teaching. Guilford Publications.

[31] Herzberg, F. (1968). One more time: How do you motivate employees? College education press.

[32] Martínez, L., Rodriguez, R. M., \& Herrera, F. (2015). 2-Tuple Linguistic Model. In The 2-tuple Linguistic Model (pp. 23-42). Springer International Publishing.

[33] Wolfenbarger, C. D., \& Sipe, L. R. (2007). A unique visual and literary art form: Recent research on picture books. Language Arts, 84 (3), 273.

[34] Wilhelm, J. D. (2016). "You gotta be the book!" teaching engaged and reflective reading with adolescents. 